\title{
'Forget everything you have ever learned about art, and start from the beginning.' Charismatic Leadership and Art School Teaching
}

\author{
Chris Owen Anglia Ruskin University
}

\begin{abstract}
:
This article explores the nature of the art and design lecturer's role in relation to Weber's definition of charismatic leadership, and to more recent theories of transformational leadership. By reference to historical examples, the author analyses the process by which the charismatic art and design lecturer can influence students, and when necessary overcome their resistance to change. Using French and Raven's model of social power, the author goes on to investigate the contribution made by charisma to the lecturer's power to persuade, even when the lecturer may be committed to using a constructive model of the educational process. Finally, the article explores the potential of 'frame alignment' as a strategy by which charismatic lecturers can overcome the reluctance of some students to open themselves to new ways of thinking and working.
\end{abstract}

Whilst lecturers may in many ways today be seen more as facilitators and stimulants to creative thinking than as the source of wisdom and expertise they may have been in the past, their success still relies on the relationships they build with their students, and their ability to persuade those students to join them on a voyage of discovery into the visual world. The art and design lecturer still needs the power to persuade students to take a certain path in order to further their own self-discovery. That power comes from the lecturer's own identity and experience as an artist, and is often at its greatest when the lecturer possesses the kind of personality or charisma which will persuade students to trust in their lecturer's judgement and vision. Some students will still be resistant to taking that path, and the success of the lecturer may then depend on their ability to challenge the thought patterns of these reluctant learners. How, both in the past and in the present day, artist-educators have used their personality and expertise to persuade art and design students to trust in their judgement of is the subject of this article.

The history of twentieth century art provides numerous examples of important artists who have become both influential and innovative teachers. The list might include Paul Klee and Wassily Kandinsky at the Bauhaus in the 1920's, Richard Hamilton and Victor Pasmore at Newcastle in the 50's, Joseph Beuys in Dusseldorf in the 70's, and Michael Craig Martin at Goldsmiths in the 90's. Often these artists exhibited at least some of the personality traits associated in management theory with charismatic leaders. It was Max Weber who first proposed a theory of charismatic leadership in 1947 . He defined charisma as :

a certain quality of an individual personality, by virtue of which he is set apart from ordinary men and treated as endowed with supernatural, superhuman, or at least specifically exceptional powers or qualities. These are not accessible to the ordinary 
person, but are regarded as of divine origin or as exemplary, and on the basis of them the individual concerned is treated as a leader. (Weber 1947)

This 'superhuman' face of charismatic leadership has echoes of the popular romantic concept of the artist, as the creative genius whose work is promoted by a small band of devoted followers. Giorgio Vasari, a student of Michelangelo, first created the myth of the supernaturally gifted artist. According to Vasari, 'the benign ruler of heaven' decided to send 'into the world an artist who would be skilled in each and every craft', and he determined to give Michelangelo 'the knowledge of true moral philosophy and the gift of poetic expression, so that everyone might admire and follow him as their perfect exemplar in life, work, and behaviour and in every endeavour, and he would be acclaimed as divine.' (Vasari 1965: 325)

These pseudo-religious connotations of the concept of charisma did not end with the 'divine Michelangelo'. They can be seen, for example, in descriptions and photographs of Johannes Itten as a teacher at the Weimar Bauhaus. With shaven head and dressed in robes, he integrated the spiritual beliefs of Mazdaznan into the Preliminary Course curriculum, and drew about him a group of devoted disciples. As a student, Paul Citroen observed, 'there was something demonic about Itten. As a Master he was either ardently admired or just as ardently hated by his opponents, of whom there were many' (Droste 2002: 32). Itten's charisma and influence became so disruptive to Walter Gropius' vision for the direction of the Bauhaus that the director contrived to force his resignation in 1922.

The pioneers of the Bauhaus-derived Basic Design course in Art \& Design in Britain in the 1950's and 60's, Richard Hamilton, Victor Pasmore and Harry Thubron, also brought powerfully charismatic personalities to bear on their teaching. Derek Page, a student of Harry Thubron at Leeds College of Art in 1962, remembered entering the studio one day to find all the teaching staff sitting at Thubron's feet, listening to him like a religious leader (Owen 1999).

These observations suggest the powerful influence which can be exerted on their followers or students by charismatic artists who, it might be argued, as teachers possess Weber's 'truly exceptional powers or qualities'. It should be noted that these historical examples all refer to men, and derive from cultures in which diversity in both the art world and the academy was rare. It does not of course follow that in today's studios there should be any lack of women and men from ethnic minorities with similar degrees of charismatic power.

The concept of charismatic leadership has been defined in more down to earth terms by management theorists in the years since Weber (Shamir et al. 1993; Conger \& Kanungo 1998). In general, these theories indicate that charismatic leaders exercise influence on their followers through charm, grace and self-belief rather than any form of external power or authority. Robert House analysed the personality characteristics and behaviours of charismatic leaders, as well as their effects on followers (House 1977). His analysis is neatly summarised by Peter G. Northouse (2010: 174) in the following table : 


\begin{tabular}{|l|l|l|}
\hline Personality Characteristics & Behaviours & Effects on followers \\
Dominant & Sets strong role model & Trust in leader's ideology \\
Desire to influence & Shows competence & Belief similarity between \\
Self-confident & Articulates goals & leader and followers \\
Strong moral values & Communicates high & Unquestioning acceptance \\
& expectations & Affection toward leader \\
& Expresses confidence & Emotional involvement \\
& Arouses motives & Heightened goals \\
& & Increased confidence \\
\hline
\end{tabular}

Charismatic leadership is a type of transformational, as opposed to transactional, leadership. This distinction was first proposed by Burns (1978). The transformational leader enhances the motivation, morale and performance of followers, by redesigning perceptions and values, and by changing expectations and aspirations. It is not based on an exchange model (the transactional approach), with rewards being given for good work, and negative feedback for poor outcomes (a give and take approach), but is based on the leader's character, and their ability to motivate change through example and the articulation of a vision. Conger \& Kanungo (1998) described five behaviours of charismatic leaders which are also common to a transformational viewpoint:

Vision and articulation;

Sensitivity to the environment;

Sensitivity to member needs;

Personal risk taking;

Performing unconventional behaviour.

These last two behaviours are particularly pertinent in relation to art and design. The charismatic art lecturer uses their strength of character to take risks, ask bold questions of the students, and to challenge conventional behaviour or thinking.

One important distinction is made between charismatic and transformational leaders. Transformational leaders are focussed on transforming their teams and organizations. Charismatic leaders tend to be very self-confident in their own vision, but that vision may not be in tune with the values of, or lead to change in, the organisation itself. This can be dangerous for the well-being of an organisation. For their followers, success is directly due to the presence of their leader. Charismatic leadership therefore carries great responsibility, and success is highly reliant on keeping that leader in post. But that vision may not be in tune with the values of, or lead to change in, the organisation itself. This can be dangerous for the well-being of an organisation, and some of the historical examples discussed here demonstrate the tensions which can be created by the actions of charismatic artists within organisations. Itten, Thubron and Beuys all came to blows with their respective institutions at one time or another. 
Fiol, Harris and House argued, in a paper published in 1999, Charismatic Leadership: Strategies For Effecting Social Change, that a range of theories encompassing charismatic leadership, visionary leadership, and transformational leadership, should together be labelled as 'the neo-charismatic leadership paradigm'. They pointed to detailed studies of these theories which have suggested a correlation between these charismatic qualities and an enhanced ability to deliver transformational change to adherents and organisations :

The theories of the neo-charismatic paradigm have been subjected to more than one hundred empirical tests. Collectively, the empirical findings demonstrate with surprising consistency that leaders described as charismatic, transformational, or visionary cause followers to become highly committed to the leader's mission, to make significant personal sacrifices in the interest of the mission, and to perform above and beyond the call of duty. The findings also demonstrate that such leaders have positive effects on their organizations. (Fiol et al. 1999: 378)

These studies have mainly been focussed on leadership in very large organisations. Some of the most interesting case studies of Robert House, for example, have analysed the language and behaviour of US Presidents, in order to evaluate their charismatic effects (House et al. 1991).

Their audience size may be very different, but it is not difficult to see a correlation between the qualities of the charismatic political leader and those of the influential teacher. Teachers may not lead nations, but they do lead their students to engage with their subject, and to believe in a vision for their futures. They do this by demonstrating strength of personality, in terms of desire, confidence and vision.

An analysis of the process of transformational leadership carried out by Bass (1985) can help us to identify more clearly how a teacher's leadership behaviours relate to the teaching process itself. Bass argued that transformational leadership is the synthesis of three components - charisma, individualized consideration, and intellectual stimulation. If we were to replace in Bass' interpretation the terms 'leaders' and 'subordinates' with 'lecturers' and 'students', his analysis would run as follows. Charisma is defined as a function of students' belief in a lecturer and their mission, and of their admiration for, trust in, and devotion to that lecturer. Charismatic lecturers are considered by their students to be dynamic, hard-working, confident, attractive, competent, and successful. Bass also describes a sub-category of charisma - inspiration. He argues that inspirational leaders (lecturers) are emotionally arousing, animating, and enlivening. The second component is individualized consideration. This could be associated with lecturers who treat students differently according to individual needs and abilities. Individualized consideration includes thoughtfulness for others and individual mentoring. The third component of transformational leadership is intellectual stimulation. This component of leadership might be associated with lecturers who stimulate extra effort among their students by forcing them to rethink ideas that they may have never questioned before (Bass, 1985). 
Citing a number of articles published over the previous 17 years, D.L. Treslan (2006) cites a range of studies in which educational researchers have attempted to evaluate the influence of this type of leadership theory when it is applied in the classroom. Treslan concludes that these studies have indeed provided evidence that, by using transformational leadership behaviours, teachers can positively influence student behaviour and perceptions. To take one example, Pounder (2008) found that teachers perceived as 'transformational', can stimulate extra effort from students, an increase in students' perceptions of leader effectiveness, and increased student satisfaction with their teachers. Another study, by Bolkan and Goodboy (2009), based on survey data from a sample of 165 students, concluded that all three components of transformational leadership are moderately to strongly associated with improvements in student learning outcomes, participation, and perceptions of teacher credibility.

None of this will come as a surprise to lecturers engaged in teaching Art \& Design in postcompulsory education. This field work has not been carried out in the context of creative educational environments, but its transferability seems on the face of it to be self-evident. As Dineen and Collins have pointed out, despite the emphasis on individualised learning and self-initiated briefs in art and design studio teaching, 'the biggest single influence on the atmosphere in any classroom is the teacher/lecturer. Successful lecturers (in terms of fostering creativity) are themselves self-motivated, creative thinkers, acting as models for their students' (2005, p. 46).

In recent years, there have been several empirical studies of how artists construct their own identities as educators, and how they negotiate the relationship between these different identities (Adams, 2007, Shreeve, 2009, Orr, 2011). But the relationship between these artist-educators and their students has been less well documented. Limited insights into students' relationship to their lecturers can be gleaned from studies of student engagement with the National Student Survey (Vaughan, D. \& Yorke, M 2009; Blair, B., Orr, S. \& Yorke, M. 2012; Orr, Yorke and Blair, 2014), but as this quote suggests, these are normally related to the messages received, rather than the personality of the lecturer : 'I am starting to realize that they're not trying to tell us to do anything, they're just trying to give us ideas to do it ourselves in the end' (Orr, Yorke and Blair, 2014). We can at present only fall back on anecdotal evidence of the impact of charismatic personalities on students. Empirical research into the influence of charismatic art and design lecturers today would be a welcome addition to art and design pedagogic literature.

Whether they are political leaders or teachers, charismatic leaders attract and influence followers, because they are admired and respected. Not all art and design lecturers could be described as exceptional in the way that maybe Itten or Thubron seem to have been, but many still use their charisma to exert considerable persuasive power over their students. This may be a discomforting thought, as the exercise of power (and charismatic power in particular) is not the way many of us would wish to interpret the teaching process, especially since with power also comes the potential for abuse. 
As Foucault suggested, 'power is not an institution, and not a structure; neither is it a certain strength we are endowed with; it is the name that one attributes to a complex strategical situation in a particular society' $(1978$, p.93). In the microcosm of society represented by the classroom or studio, that strategical situation presents the lecturer with considerable power to influence students, and it is important to try to understand how that power can be used to liberate rather than stifle students' creativity. Where does this power come from? And what is the relationship between charisma and power in art school teaching ? Sociological and management theories can be valuable aids in answering this question.

French and Raven (1960) in their classic study defined five sources of social power :

Coercive power - the power to force someone to do something against their will.

Reward power - the ability to give other people what they want, and hence ask them to do things for you in exchange.

Legitimate power - the power which is invested in a role, or position of power.

Referent power - the power which derives from another person liking you or wanting to be like you, and therefore the power most clearly related to charisma.

Expert power - the power which is held by having knowledge and skills which someone else requires

Raven (1965) later added a sixth source :

Informational power - the power to provide information to a person that results in them thinking/acting in a different way.

With the exception of coercive power, art and design lecturers possess all these powers in different proportions. They should all be able to exercise legitimate, reward and expert powers. They have authority by virtue of their role as lecturers. They possess reward power (although they might not recognise this) in being able to help their students to develop their abilities and start out on a creative career. And they do this through passing on their expertise - in the form of experience and knowledge - as part of the give and take of the teaching process.

The other two sources of power - referent power and informational power - are enhanced by what we would term charisma. The more charismatic the lecturer, the more he or she will also be admired by their students as role models, and the more trust will be generated, when he or she tries to persuade their students to work in a different way.

Personal charisma is an important determinant of the lecturer's power to persuade, but it is not sufficient on its own. The other key factor in determining power is the authority created by the lecturer's expertise. The ability to exercise their legitimate power is greatly weakened, if that status is not backed up by appropriate skills and experience - expert power. And it is only by possessing expert power that it becomes possible to exercise reward power, referent power, or informational power : 


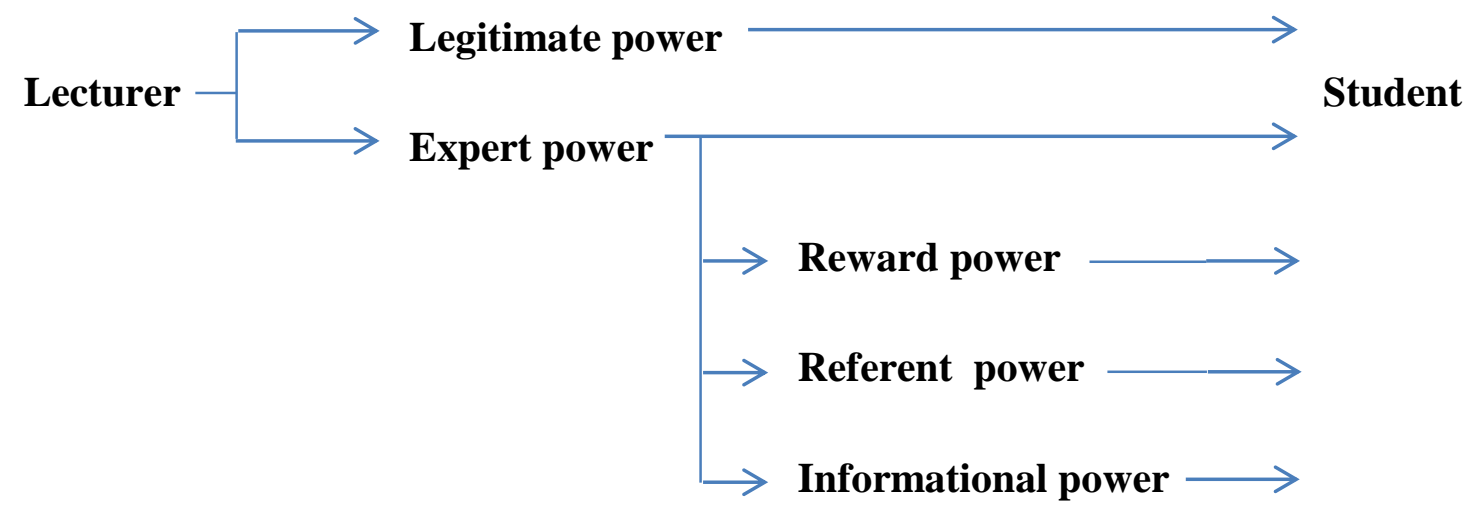

Modern theories of charismatic leadership, derived from Weber's work, can also help to explain how lecturers in schools of art and design use this power of personality in the process of teaching itself. Fiol et al. (1999) analysed the process by which charismatic leaders influence behavioural change in their followers. They started from the concept of frame alignment, developed by Snow et al. (1986) and first applied to leadership theory by Shamir et al. (1993). Frame alignment refers to a shift in individual and leader interpretive orientation, so that some set of followers' interests, values, and beliefs and the leader's activities, goals, and ideology (the 'frames') are brought into line. Fiol et al. argue that :

To achieve frame alignment, charismatic leaders engage the self-concepts of followers in the mission articulated by the leader. Strong engagement of the selfconcept of followers makes it cognitively dissonant for them not to behave in ways that further mission accomplishment. Charismatic leaders increase the intrinsic value of follower efforts in pursuit of mission accomplishment by linking effort and goals to valued aspects of the follower's self-concept, thus harnessing the motivational forces of self-expression, self-consistency, self-esteem, and self-worth. (Fiol et al. 1999: 382)

In other words, charismatic leaders / teachers find ways to appeal to their followers' / students' ideas of their own identity, in order to win them over to support their leader's / teacher's own view / values / goals. In doing so, they effect a shift in the frame of reference of these followers / students.

Frame alignment is an interesting concept when applied to the teaching of Art \& Design. It seems to be particularly relevant to that part of the lecturer's role which is to move students out of their comfort zone, to persuade them to think in new ways - and this, it might be argued, is a key process in teaching students to think creatively. As Dineen \& Collins (2005) state, for students 'the route-map does not exist. The explorer must find his/her own way through territory which is at least partly uncharted....There is a sense of direction, but, at 
least at first, no certainty of the steps or knowledge needed to arrive.' Trust in the lecturer to help them find their way through this uncharted territory is critical to each student's success, and this is where frame alignment is important.

As a student of Victor Pasmore at Newcastle in 1956, Rita Donagh recalled his attempts at what might now be called frame alignment: 'Victor was doing this extraordinary session once every week when he just tried to make you forget everything you had ever learned about art and start from the beginning.' (Yeomans 1987: 192). He was trying to realign the students' frame of thinking, and the charismatic quality of Pasmore's teaching must have been very evident to this student, as she continued, 'It was almost like the laying on of hands - to my memory of it, it was very mystical'. For the Foundation Diploma teacher today, trying to break down what is perceived as a formulaic quality in a student's approach to their work, or the Illustration lecturer trying to persuade a narrowly focussed student that Manga is not the only way to create a narrative through pictures, frame alignment may not be mystical or even a conscious process, but it is still a fundamental part of the act of teaching.

Fiol et al. go on to use semiotics as a means to analyse how this process of frame alignment is most effectively tackled. They construct two semiotic visual representations of a value's contradictions and contraries. The first represents the alignment of convention and innovation, when they are viewed as semiotically contrary values. Any change-goal of a leader is likely to involve a shift in attitude from convention to its semiotic contrary (or opposite), innovation. In Art and Design teaching, the process of change from conventional to innovative thinking in this model perhaps has an enhanced significance. The diagram illustrates each contrary value in the top left and right of the square. Their semiotic contradictions (or negations) - non-convention and non-innovation - appear diagonally opposite to each of these contrary values :

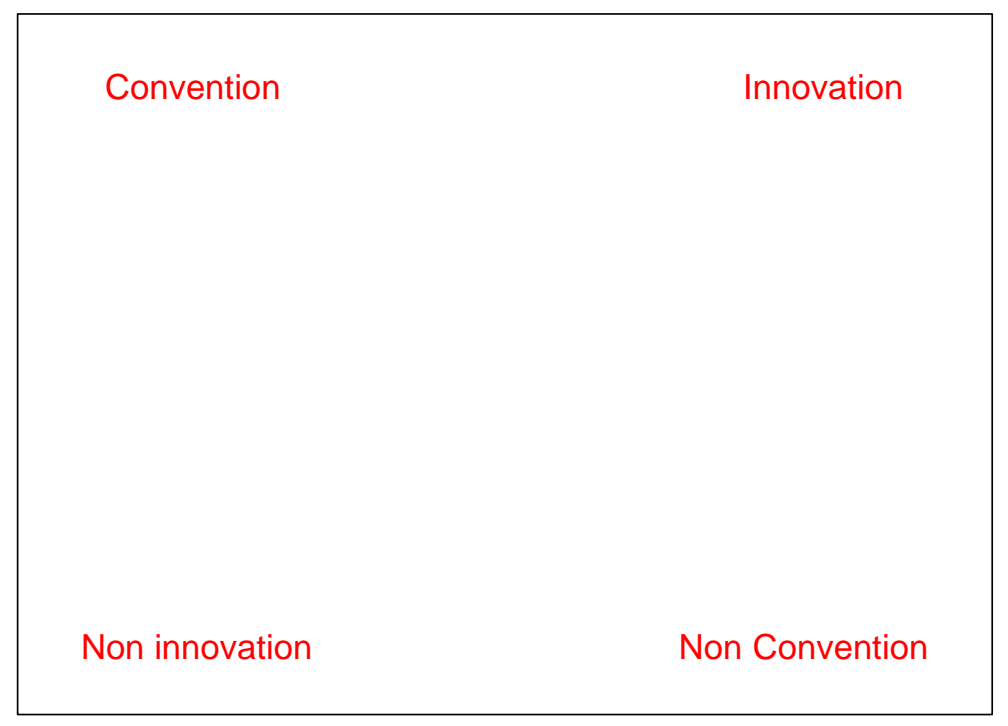

A key barrier to change is fear, and a pre-requisite for welcoming change is desire. These contraries, and their contradictions, can be represented by a similar diagram : 
Frame alignment occurs when the leader or teacher (with a desire for innovation / fear of convention) attempts to change the attitude of followers or students (with a desire for convention / fear of innovation) to move from convention to innovation. This requires movement from fear of innovation to desire for it. Citing Lewin (1951), the authors explain that the most effective means of achieving this is to do so indirectly :

Replacing one dominant value with another directly (e.g., replacing convention with innovation), or shifting the balance of one in favour of the other, will lead to increasing tension that is likely to undermine change efforts. According to Lewin, an effective change strategy begins by 'unfreezing' the dominant value. Here, this means advocating its contradiction (e.g., replacing convention with non-convention before advocating innovation)

The process of frame alignment therefore needs to start by moving diagonally across the square, not directly across it, from fear / convention to non-fear / non convention, to desire / innovation :

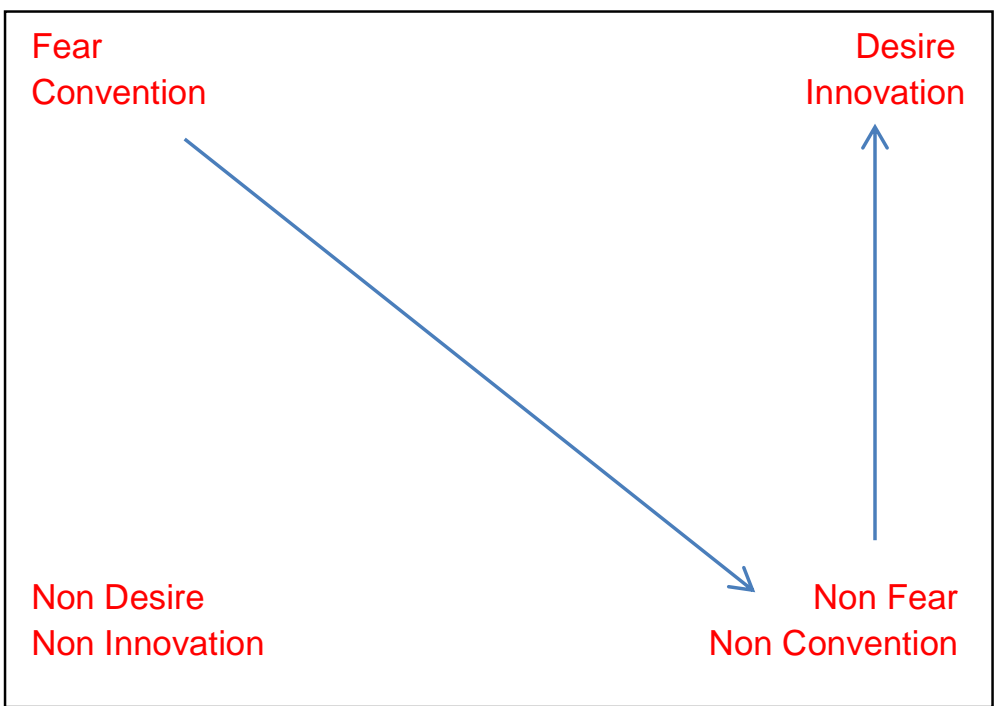


Continuing to argue that charismatic leaders of necessity oppose conventional thinking, Fiol et al. conclude that 'according to this model, negation of existing beliefs is a fundamental characteristic of charismatic leadership' (1999: 389).

Following this model, it may be argued that it is pedagogically appropriate to start, as Pasmore did (and others have done since), by persuading students to 'forget everything you have ever learned about art and start from the beginning', before building a new frame of the artistic process.

The charismatic lecturer tries to realign or even transform a student's frame of reference, but how do we expect the student to respond? What happens if the lecturer, in spite of all their charisma and powers of persuasion, struggles to link 'effort and goals to valued aspects of the follower's self-concept, thus harnessing the motivational forces of self-expression, self-consistency, self-esteem, and self-worth' (Fiol et al. 1999: 382) ? Moving from the lecturer's perspective to that of the student, we may be able to learn further lessons from management theory about how this process of frame alignment works.

Art and Design teaching can be seen partly as a form of change management. As Machiavelli pointed out in The Prince, 'there is nothing more difficult to take in hand, more perilous to conduct, or more uncertain in its success, than to take the lead in the introduction of a new order of things' (Machiavelli 1513: Ch VI). Different types of change require different types of management, as Johnson, Whittington and Scholes have pointed out, using the table below (2008: 520):

\begin{tabular}{|l|l|l|l|}
\cline { 3 - 4 } \multicolumn{2}{|c|}{} & \multicolumn{2}{c|}{ Extent of Change } \\
\cline { 3 - 4 } Nature of change & Realignment & Transformation \\
\cline { 3 - 4 } & Big Bang & Adaptation & Evolution \\
\hline
\end{tabular}

The dominant personality, self confidence and desire to influence which are characteristics of the charismatic lecturer (Northouse 2010) are more likely to favour radical change - the big bang transformation - than the incremental realignment of student behaviour which less single-minded teachers might prefer. The charismatic teacher will therefore be more likely to try to effect a revolution in the student's approach to their subject. And the greater the change, the more likely it is that they will encounter resistance, from individuals or from the whole class of students.

Resistance to change in established behaviours is a normal human reaction, and to be successful the lecturer must understand the reasons for the individual student's reluctance to 
change. The student may see nothing wrong with the way they already work. They may feel that the risks associated with change outweigh the benefits, or they may not see the purpose in working in the new way that is proposed. We have all encountered the student who asks, 'But why are we doing this ?' It takes a lot of charisma to win over that student with the answer, 'Trust me; you may not be able to understand this now, but you will see the point of it later'. The changes of attitude or thought process which we ask our students to tackle in their approach to their work can be painful for some of them to accept. The charismatic lecturer creates the trust which is required for these students to work their way through the change process. The students may suffer the pain of initial confusion and possibly of repeated failures, but they do so in the hope of a more creative and successful future, trusting in the persuasive authority of their charismatic leader. 


\section{References :}

Adams, J. (2007) Artists becoming teachers: expressions of identity transformation in a virtual

forum, International Journal of Art and Design Education, Vol. 26, No. 3, pp. 264-73

Blair, B., Orr, S. \& Yorke, M. (2012) 'Erm, that question... I think I probably would've just put something in the middle and sort of moved on to the next one, because I think it's really unclear': How Art and Design Students Understand and Interpret the National Student Survey (online). Available at: http://www. heacademy.ac.uk/resources/detail/disciplines/art-anddesign/GLAD _ report__ April2012

Bolkan, S and Goodboy, A.K. (2009) Transformational Leadership in the Classroom: Fostering Student Learning, Student Participation, and Teacher Credibility, Journal of Instructional Psychology, Dec2009, Vol. 36 Issue 4, p296-306

Burns, J.M. (1978) Leadership. New York. Harper \& Row

Conger, J. A., and R. N. Kanungo (eds) (1998) Charismatic Leadership in Organizations. Thousand Oaks, CA: Sage Publications,

Dineen, R. \& Collins, E. (2005) 'Killing the goose: conflicts between pedagogy and politics in the delivery of a creative education', Journal of Art \& Design Education, Vol. 24, No. 1, pp. $43-51$

Droste, M. (2002) Bauhaus, 1919-1933, Bauhaus-Archiv, p.32

Fiol et al. (1999) Fiol, C.M. Harris, D. \& House, R. Charismatic Leadership: Strategies for Effecting Social Change, Leadership Quarterly, No 3, Fall. pp. $375 f$.

Foucault, M. (1978) The History of Sexuality vol. 1, trans. Robert Hurley, Allen Lane.

French, J. P. R. Jr., and Raven, B. (1960). 'The bases of social power', in D. Cartwright and A. Zander (eds.), Group Dynamics (pp. 607-623). New York: Harper and Row.

House, R.J. (1977) 'A 1976 theory of charismatic leadership'. In J. G. Hunt and L. L. Larson (eds.), Leadership: The Cutting Edge: 189-207. Carbondale, IL: Southern Illinois University Press.

House et al. (1991) House, R.J., Spangler, W.D. and Woycke, J Personality and Charisma in the U.S. Presidency: A Psychological Theory of Leader Effectiveness Administrative, Science Quarterly, Vol. 36, No. 3 (Sept), pp. 364-396

Johnson, G., Whittington K., and Scholes R. (2008) Exploring Corporate Strategy, $8^{\text {th }}$ Edition, Prentice Hall 
Lewin, K (1951) Field Theory in Social Science: selected theoretical papers (Edited by D. Cartwright) Harpers, Oxford.

Machiavelli, N (1513, trans. W. K. Marriott 1908) The Prince, Project Gutenberg.

Northouse, P.G. (2010) Leadership; Theory and Practice, $5^{\text {th }}$ ed. Sage Publications (CA), p. 174

Orr, S. (2011), "Being an Artist You Kind of, I Mean, You Get Used to Excellence": Identity, Values and Fine Art Assessment Practices, International Journal of Art \& Design Education, Vol.30(1), p.37-44

Orr, Susan ; Yorke, Mantz ; Blair, Bernadette (2014) 'The answer is brought about from within you': A Student-Centred Perspective on Pedagogy in Art and Design, International Journal of Art \& Design Education, Feb, Vol.33(1), p.32-45

Owen, C. (1999) A Challenging Process; 40 years of the Art \& Design Foundation Course, unpublished MEd thesis, Huddersfield University

Pounder, J.S. (2008). Transformational classroom leadership: A novel approach to evaluating classroom performance. Assessment \& Evaluation in Higher Education, 33, pp.233-243.

Raven, B. H. (1965). 'Social influence and power'. In I.D. Steiner \& M. Fishbein (Eds.), Current Studies in Social Psychology (pp. 371-382). New York: Holt, Rinehart, Winston

Shamir et al. (1993) Shamir, B., House, R.J. and Arthur, M.B. The Motivational Effects of Charismatic Leadership: A Self-Concept Based Theory. Organization Science Vol. 4, No. 4 (Nov), pp. 577-594

Shreeve, A. (2009) 'I'd rather be seen as a practitioner, come in to teach my subject': Identity Work in Part-Time Art and Design Tutors, International Journal of Art \& Design Education, Vol.28(2), pp.151-159

Snow et al (1986) Snow D.A., Rochford E.B., Worden S.K., and Benford R.D. Frame Alignment Processes, Micromobilization and Movement Participation. American Sociological Review 51:pp. 464-81.

Treslan, D.L. (2006) Transformational Leadership in the Classroom: Any Evidence? Education Canada, v46 n2 p58-62 Spring

Vasari, G. (1965) Lives of the Artists, a Selection. Trans. G. Bull, London, p. 325

Vaughan, D. \& Yorke, M (2009) 'I can't believe it's not better': the paradox of NSS scores for art \& design, York: The Higher Education Academy. P.41f.

Weber, M. (1947) Theory of Social and Economic Organization. Chapter: 'The Nature of Charismatic Authority and its Routinization' translated by A. R. Anderson and Talcott Parsons. Originally published in 1922 in German under the title Wirtschaft und Gesellschaft chapter III, $\S 10$ 
Yeomans, R. (1987), The Foundation Course of Victor Pasmore and Richard Hamilton, Unpublished $\mathrm{PhD}$ thesis, London Institute of Education. 